\title{
The issues in chromium-containing wastewater treatment by sodium pyrosulfite
}

\author{
Zhiyong $\mathrm{Wu}^{1, \mathrm{a}^{*}}$, Jie Feng ${ }^{2, \mathrm{~b}}$ and Zuoqin Tang ${ }^{3, \mathrm{c}}$ \\ Institute of machinery manufacturing technology, China academy of engineering physics, Mianyang, \\ 621900, China \\ awuyan61@163.com, ${ }^{\mathrm{b}}$ fengjie210@163.com, ${ }^{\mathrm{c}} 1399832273 @ q q . c o m$
}

Keywords: chromium-containing wastewater, redox, chemical precipitation.

Abstract. It was found that appropriately increase weight ratio as well as attention to control $\mathrm{pH}$ in sedimentation and reduction phases can enhance the treatment effect of chromium-containing wastewater and prevent hexavalent chromium content rebounding after processing.

\section{Introduction}

Chromium-containing wastewater has great harm to environment, biology and human body, while chromium pollution is one of the important factors of environment pollution ${ }^{[1,2]}$. Our organization which always attach importance to chromium-containing wastewater, collocate with professional processing flow, operating personnel and analyst responsible for monitoring treated wastewater ${ }^{[4]}$.

Several common methods for chromium-containing wastewater at present including : electrolytic reduction, chemical precipitation, ion exchange, photocatalysis method etc ${ }^{[5,6]}$. Our organization has used successively ion exchange, ferrous sulfate reduction method in chromium-containing wastewater treatment. The advantage of ion exchange method contains better water quality after processing and the water and chromic acid can be reused, while the shortage are high investment and maintenance costs, complicated operation administration and resin oxidation problem. The main disadvantages of ferrous sulfate reduction method are large quantity of sludge and secondary pollution ${ }^{[7]}$.

Currently our organization take use of sodium pyrosulfite in chromium-containing wastewater treatment which has an easy operation procedure and get a stable and desirable effect, discharge water $100 \%$ up to the standard. The water after treatment has a better quality and less sludge and cost. The next tests show that considering these following points can get better effect.

\section{Materials and methods}

Experimental procedures. General procedure of chromium-containing wastewater treatment by sodium pyrosulfite: adjust $\mathrm{pH}$ to acidic $\rightarrow$ put in sodium pyrosulfite to degrade $\mathrm{Cr}^{6+}$ to $\mathrm{Cr}^{3+} \rightarrow$ adjust $\mathrm{pH}$ to 6-9 to deposit $\mathrm{Cr}^{3+} \rightarrow$ discharge supernatant and process sedimentation intensively.

Analyses. The preparation of chromium-containing solution $\left(1.00 \mathrm{~g} / 1 \mathrm{Cr}^{6+}\right)$ : accurately weigh $2.8329 \mathrm{~g}$ potassium dichromate (AR) dissolved in $1000 \mathrm{ml}$ volumetric flask, then dilute to calibration and shake well.

The basic analytical principles : $\mathrm{Cr}^{6+}$ can react with diphenyl carbazide to form a purplish red complex in acid, which can be measured by $721 \mathrm{E}$ spectrophotometer。

\section{Results and discussion}

Effect of pH and weight ratio. Treatment by sodium pyrosulfite in reduction phase.

The reaction process is as Eq. 1 :

$$
2 \mathrm{Cr}_{2} \mathrm{O}_{7}{ }^{2-}+3 \mathrm{~S}_{2} \mathrm{O}_{5}{ }^{2-}+10 \mathrm{H}^{+} \rightarrow 4 \mathrm{Cr}^{3+}+6 \mathrm{SO}_{4}{ }^{2-}+5 \mathrm{H}_{2} \mathrm{O}
$$


$\mathrm{Cr}^{6+}$ has a great oxidability in the acidic condition, therefore adjust the solution to be acidic before reduction.

As shown in table 1, even there is a better effect in lower $\mathrm{pH}$, but excessively low $\mathrm{pH}$ make sodium pyrosulfite is easy to decompose and generate $\mathrm{SO}_{2}$, in addition, it will consume more alkali to adjust $\mathrm{pH}$ before discharge as a result increase the cost. Therefore the optimum $\mathrm{pH}$ is 3.0 for this study.

Table 1 Variations of degradation of $\mathrm{Cr}^{6+}$ concentrate with $\mathrm{pH}$ in reduction phase by sodium pyrosulfite

\begin{tabular}{|c|c|c|c|c|c|c|}
\hline \multirow{2}{*}{\begin{tabular}{l}
\multicolumn{1}{c}{$\mathrm{Cr}^{6+}$} \\
concentrate \\
before \\
processing \\
{$[\mathrm{g} / \mathrm{L}]$}
\end{tabular}} & \multirow[b]{2}{*}{$\mathrm{pH}$} & \multicolumn{3}{|c|}{$\begin{array}{c}\mathrm{Cr}^{6+} \text { concentrate after processing } \\
{[\mathrm{mg} / \mathrm{L}]}\end{array}$} & \multirow{2}{*}{$\begin{array}{l}\text { Reaction } \\
\text { time[min] }\end{array}$} & \multirow{2}{*}{\begin{tabular}{l}
\multicolumn{1}{c}{ The pH of } \\
solution after \\
processing
\end{tabular}} \\
\hline & & $\begin{array}{c}\mathrm{Na}_{2} \mathrm{~S}_{2} \mathrm{O}_{5} \\
\text { dosage } 2.8 \mathrm{~g} / \mathrm{L}\end{array}$ & \begin{tabular}{|c}
$\mathrm{Na}_{2} \mathrm{~S}_{2} \mathrm{O}$ \\
5 dosage \\
$3.2 \mathrm{~g} / \mathrm{L}$ \\
\end{tabular} & $\begin{array}{r}\mathrm{Na}_{2} \mathrm{~S}_{2} \mathrm{O}_{5} \\
\text { dosage } 4 \mathrm{~g} / \mathrm{L}\end{array}$ & & \\
\hline 1.0 & 1.2 & 200 & 0.02 & -- & $<10$ & 2.1 \\
\hline 1.0 & 2.8 & 200 & 0.02 & -- & $<30$ & 3.3 \\
\hline 1.0 & 3.7 & 200 & 0.34 & 0.02 & $>30$ & 4.2 \\
\hline 1.0 & 4.8 & 800 & 1.36 & 0.8 & $>30$ & 4.8 \\
\hline
\end{tabular}

Table 2 Variations of sedimentation efficiency and degradation of total chromium concentrate with pH in sedimentation phase

\begin{tabular}{|c|c|c|}
\hline $\mathrm{pH}$ & Phenomenon & $\begin{array}{l}\quad \text { Total } \\
\text { concentrate in } \\
{[\mathrm{mg} / \mathrm{L}]}\end{array}$ \\
\hline 6.9 & $\begin{array}{l}\text { Precipitation is obvious and } \\
\text { solution is wathet }\end{array}$ & 12.1 \\
\hline 7.6 & $\begin{array}{l}\text { Large precipitation and solution } \\
\text { is wathet }\end{array}$ & 2.6 \\
\hline 8.1 & $\begin{array}{l}\text { Large precipitation and solution } \\
\text { is colorless and transparent }\end{array}$ & 1.4 \\
\hline 8.8 & $\begin{array}{l}\text { Large precipitation and solution } \\
\text { is colorless and transparent }\end{array}$ & 0.06 \\
\hline 9.3 & $\begin{array}{l}\text { Large precipitation and solution } \\
\text { is colorless and transparent }\end{array}$ & 0.45 \\
\hline 10.3 & $\begin{array}{l}\text { Large precipitation and solution } \\
\text { is colorless and transparent }\end{array}$ & 1.97 \\
\hline
\end{tabular}

In sedimentation phase, after oxidation-reduction reaction adjust $\mathrm{pH}$ to 7-9 with $\mathrm{NaOH}$. The reaction process is as Eq. 2 :

$\mathrm{Cr}^{3+}+3 \mathrm{OH}^{-} \rightarrow \mathrm{Cr}(\mathrm{OH})_{3} \downarrow$

When the $\mathrm{pH}$ is over $9, \mathrm{Cr}(\mathrm{OH})_{3}$ is apt to redissolve. When $\mathrm{pH}$ is under 6 , it can't precipitate.

According to table 2 effluent total chromium concentrate is comparatively high as $\mathrm{pH}$ under 7 . When the $\mathrm{pH}$ is between 7.6 9.3, total chromium concentrate is between $0.45 \sim 2.6 \mathrm{mg} / \mathrm{L}$. effluent total chromium concentrate is over $1.5 \mathrm{mg} / \mathrm{L}$ as the $\mathrm{pH}$ over 10 . Considering the chromium concentrate of actual wastewater is about $30 \mathrm{mg} / \mathrm{L}$ commonly which is much less than the $1.0 \mathrm{~g} / \mathrm{L}$ experimental concentrate, so $\mathrm{pH}$ should be adjusted to 7-9 to meet the discharge standard. 
Weight ratio. Table 1 also reveals that with the increase of sodium pyrosulfite the $\mathrm{Cr}^{6+}$ concentrate after processing decreases obviously. Calculated as the reaction between sodium pyrosulfite and $\mathrm{Cr}^{6+}$, the theoretical weight ratio $\mathrm{Cr}^{6+}: \mathrm{Na}_{2} \mathrm{~S}_{2} \mathrm{O}_{5}=1: 2.74$. But in actual operation, the weight ratio $\mathrm{Cr}^{6+}$ : $\mathrm{Na}_{2} \mathrm{~S}_{2} \mathrm{O}_{5}$ ranges from 1:3.5-1:4, one the one hand the content of industrial sodium pyrosulfite is very low, on the other hand ensure processing $\mathrm{Cr}^{6+}$ can once finished to avoid the rework cost.

The rebound of Cr6+ after processing. When the $\mathrm{Cr}^{6+}$ concentrate in supernate is under $0.5 \mathrm{mg} / \mathrm{L}$, discharge the solution. Nevertheless the content of $\mathrm{Cr}^{6+}$ will rebound and exceed the standard from analysis. That is because there is a small amount of $\mathrm{Cr}(\mathrm{OH})_{3}$ and $\mathrm{Cr}^{3+}$ in supernate which can turn to $\mathrm{Cr}^{6+}$ under certain conditions. The transform reaction process is as Eq. 3:

$4 \mathrm{Cr}(\mathrm{OH})_{3}+3 \mathrm{O}_{2}+8 \mathrm{OH}^{-} \rightarrow 4 \mathrm{CrO}_{4}{ }^{2-}+10 \mathrm{H}_{2} \mathrm{O}$

In order to get reliable consequence, $\mathrm{Cr}^{6+}$ concentrate after processing should be under $0.1 \mathrm{mg} / \mathrm{L}$, and solution $\mathrm{pH}$ after processing should adjust to be between 7-9.

\section{Conclusions}

The statistics show that workshop has consumed about $4000 \mathrm{Kg} \mathrm{Na}_{2} \mathrm{~S}_{2} \mathrm{O}_{5} 3$ times of the theoretical calculation value to process chromium-containing wastewater in 2006. The primary cause is improper solution $\mathrm{pH}$ control which is the critical factor to influence $\mathrm{Cr}^{6+}$ transform to $\mathrm{Cr}^{3+}$.

In order to get the desirable effect, the following 3 factors should be considered:

(1) Adjust the $\mathrm{pH}=3$ in reduction phase for adequate reaction.

(2) Keep $\mathrm{pH}=7-9$ in sedimentation phase to precipitate $\mathrm{Cr}^{3+}$ sufficiently and meet the discharge standard of total chromium.

(3) To avoid the rebound of $\mathrm{Cr}^{6+}$ after processing, it should increase weight ratio of $\mathrm{Cr}^{6+}$ to $\mathrm{Na}_{2} \mathrm{~S}_{2} \mathrm{O}_{5}$ as 1:3.5-1:4 in reduction phase.

In the light of the research, under the certain conditions, $\mathrm{pH}=3$ and actual operational weight ratio $\mathrm{Cr}^{6+}: \mathrm{Na}_{2} \mathrm{~S}_{2} \mathrm{O}_{5}=1: 3.5-1: 4, \mathrm{Cr}^{6+}$ can be degraded to $\mathrm{Cr}^{3+}$ completely and come up with the discharge standard. It can save about $3000 \mathrm{Kg} \mathrm{Na}_{2} \mathrm{~S}_{2} \mathrm{O}_{5}$ as this method and has already processed $1000 \mathrm{~L}$ high concentration chromic acid wastewater with great economic and environment benefits.

\section{References}

[1] Zhao Xude, Zhang Lili, Huang Qinghui, Wang Jing, Study on the treatment technology of chromium-containing wastewater from aluminum alloy production[J]; Industrial Water Treatment; 2013-06 [2]W. Strunk Jr., E.B. White, The Elements of Style, third ed., Macmillan, New York, 1979.

[2] PENG Rong-hua, ZENG Wen-nan, LI Xiao-xiang, Study on the treatment of chromium-containing wastewater by sulphonated peat coal[J]; Journal of China Coal Society; 2007-08.

[3] WU Cheng-bao, HU Xiao-fang, LUO Wei-yin, XU Jin-lai School of Industrial Equipment and Control Engineering, South China University of Technology, Guangzhou 510640, China; Discussion on treatment of chromium containing wastewater with ferrite method[J]; Electroplating \& Finishing; 2006-05.

[5] Zou Haiming, Yan Jiaping, Hua Shujia, Effect of Treatment Factor on Delating Chromium of Fly Ash in Chrominm Wastewater[J]; Anhui Agricultural Science Bulletin; 2008-11.

[6] Yang Mingping, Fu Yongjian, Li Guobin, Chromium-Containing Wastewater Treatment by Copperas Byproduct in Titanium Dioxide Production[J]; Materials Protection; 2005-06.

[7] $\mathrm{Xu}$ Weini, Discussion on Technology of Electroplate Chromium-contained Wastewater Treatment[J]; 2001-06. 